\title{
Pola Komunikasi dan Interaksi dalam E-learning Statistika Matematika Selama Covid-19
}

\author{
Istiqomah Istiqomah $^{1, *}$, Fitria Sulistyowati ${ }^{2}$ \\ ${ }^{1,2}$ Universitas Sarjanawiyata Tamansiswa \\ *istiqomah@ustjogja.ac.id
}

\begin{tabular}{|l|l|l|l|}
\hline Received : 12-03-2021 & Revised: 21-05-2021 & Accepted: 19-10-2021 & Published: $21-12-2021$ \\
\hline
\end{tabular}

\begin{abstract}
ABSTRAK
Penelitian ini merupakan penelitian deskriptif kualitatif yang bertujuan untuk mendeskripsikan perspektif mahasiswa pada aspek pola komunikasi dan interaksi dalam pembelajaran e-learning Statistika Matematika. Tahap penelitian kualitatif yaitu: (1) identifikasi masalah; (2) penelusuran kepustakaan; (3) maksud dan tujuan penelitian; (4) pengumpulan data; (5) analisa dan pelaporan data; (6) pelaporan. Subjek penelitian ini adalah seluruh mahasiwa yang mengambil mata kuliah Statitika Matematika di Prodi Pendidikan Matematika Universitas Sarjanawiyata Tamansiswa (UST) pada tahun ajaran 2019/2020. Teknik pengumpulan data yang digunakan adalah angket Skala Likert. Data dalam penelitian ini dianalisis secara statistik deskriptif. Temuan dalam penelitian ini adalah: (1) 50\% mahasiswa menganggap e-learning Statistika Matematika memberikan kemudahan dalam berinteraksi; (2) 47,02\% mahasiswa menganggap $e$ learning Statistika Matematika memberikan kemudahan dalam menjalin keakraban; (3) 61,94\% mahasiswa mengalami kesalahan komunikasi dalam e-learning Statistika Matematika; (4) 50,75\% mahasiswa menganggap e-learning Statistika Matematika memberikan kemudahan dalam mengutarakan pendapat. Temuan tersebut selanjutnya akan dijadikan acuan untuk memperbaiki pembelajaran yang akan dilakukan.
\end{abstract}

Kata Kunci : komunikasi, interaksi, e-learning

\begin{abstract}
This research is a qualitative research which aims to describe the student's perspective on the aspects of communication and interaction patterns in online learning / e-learning Mathematics Statistics. The qualitative research stages are: (1) problem identification; (2) literature search; (3) research purposes and objectives; (4) data collection; (5) data analysis and reporting; (6) reporting. The subjects of this study were all students who took the Mathematics Statistics course in the UST Mathematics Education Study Program in the 2019/2020 academic year. The data collection technique used was a Likert scale questionnaire. The data in this study were analyzed using descriptive statistics. The findings in this study are: (1) $50 \%$ of students think that e-learning Mathematics Statistics provides ease of interaction; (2) $47.02 \%$ of students think that e-learning Mathematics Statistics makes it easy to build intimacy; (3) $61.94 \%$ of students experienced communication errors in e-learning Mathematics Statistics; (4) $50.75 \%$ of students think that elearning Mathematics Statistics makes it easy to express opinions. The findings will then be used as a reference for improving the learning that will be carried out.
\end{abstract}

Keywords: communication, interaction, e-learning 


\section{PENDAHULUAN}

Pada akhir tahun 2019 dunia dikejutkan dengan munculnya suatu penyakit yang dikenal dengan istilah Covid-19 atau Corona Virus diseases-19. Virus ini mewabah pertama kali di Wuhan, China dan saat ini sudah menyebar ke seluruh dunia dengan cepat, sehingga pada 11 Maret 2020 World Health Organization (WHO) menetapkan wabah ini sebagai pandemi (Adnan, 2020; Cucinotta \& Vanelli, 2020). Adanya pandemi Covid-19 memberikan dampak signifikan dalam berbagai bidang, salah satunya bidang pendidikan (Marinoni, Van’t Land, \& Jensen, 2020). Oleh karena itu, beberapa negara di dunia menetapkan kebijakan terkait pembelajaran untuk mengurangi dampak negatif Covid-19 dalam bidang pendidikan.

Beberapa negara termasuk Indonesia menerapkan distance learning atau e-learning atau online learning sebagai strategi pembelajaran di masa pandemi Covid-19 (Chen, Kaczmarek, \& Ohyama, 2020; Churiyah, Sholikhan, Filianti, \& Sakdiyyah, 2020; Schneider \& Council, 2020). Oleh karena itu, perkuliahan Statistika Matematika di Program Studi (Prodi) Pendidikan Matematika Universitas Sarjanawiyata Tamansiswa (UST) menerapkan e-learning sebagai strategi perkuliahan di masa pandemi Covid-19 untuk meminimalkan adanya kontak fisik tetapi pembelajaran tetap dilaksanakan seperti tatap muka melalui aplikasi, internet, dan elektronik/perangkat multimedia lainnya (Moore, Dickson-Deane, \& Galyen, 2011a).

Permasalahannya adalah apakah e-learning yang menawarkan pembelajaran sepanjang waktu, bisa diakses kapan saja dan dimana saja, mampu membangun pola komunikasi dan interaksi belajar yang baik, sehingga pembelajaran dapat efektif dan efisien seperti tatap muka? (Adijaya, 2018; Sofiana, 2015). Pertanyaan tersebut tentunya juga berlaku dalam pembelajaran Statistika Matematika di Prodi Pendidikan Matematika UST yang menerapkan e-learning sebagai alternatif pembelajaran pada masa pandemi Covid-19. Langkah awal untuk menjawab pertanyaan tersebut dapat melalui penelitian yang mengungkap sudut pandang mahasiswa terhadap pola komunikasi dan interaksi belajar dalam e-learning Statistika Matematika.

Komunikasi merupakan proses penyampaian pesan dari pengirim kepada penerima dalam bentuk simbol, lambang, pikiran, perasaan ataupun perkataan (Arifin, 2006; Effendy, 1990; Inah, 2015). Contoh pengirim dalam pembelajaran adalah guru atau dosen, sedangkan penerimanya adalah siswa atau mahasiswa. Karakteristik proses komunikasi dalam pembelajaran meliputi: (1) simbolik yang berarti setiap kegiatan komunikasi melibatkan simbol-simbol seperti pesan lisan, tulisan dan pesan non-verbal; (2) dinamis 
yang berarti proses komunikasi itu berubah secara kontinyu; (3) bisa dipahami; (4) unik yang artinya setiap proses komunikasi selalu melibatkan setidaknya dua orang dengan keunikan pribadinya masing-masing (Quible, Johnson, \& Mott, 1996). Terdapat beberapa faktor yang mempengaruhi keberhasilan komunikasi yaitu: komunikator, pesan yang disampaikan, komunikan, konteks, dan sistem penyampaian (Lanani, 2013; Rizkiani \& Septian, 2019). Faktor-faktor tersebut perlu dimaksimalkan agar komunikasi dalam pembelajaran dapat berhasil sesuai dengan karakteristiknya, khususnya dalam $e$-learning.

Secara umum interaksi dapat diartikan sebagai hubungan timbal balik antara individu dengan individu, individu dengan kelompok, atau kelompok dengan kelompok lain untuk tujuan tertentu (Annas, 2017; Roestiyah, 1994). Interaksi yang terjadi selama pembelajaran meliputi interaksi satu arah, dua arah dan multi arah dalam bentuk penjelasan, diskusi, pertanyaan maupun refleksi yang digunakan untuk penyelesaian masalah (Roestiyah, 1994; Sardiman, 2000; Septian, Sugiarni, \& Monariska, 2020). Oleh karena itu, dalam e-learning perlu dirancang pola interaksi yang tepat melalui satu arah, dua arah dan multi arah dalam bentuk penjelasan, diskusi, pertanyaan maupun refleksi sehingga terjadi hubungan timbal balik antara individu dengan individu, individu dengan kelompok, atau kelompok dengan kelompok lain untuk tujuan tertentu dalam hal ini hasil belajar Statistika Matematika yang optimal.

E-learning biasanya menggunakan teknologi jaringan informasi dan komunikasi pada proses pembelajaran (Zyainuri \& Marpanaji, 2012). E-Learning adalah pembelajaran yang pelaksanaannya didukung oleh jasa teknologi seperti gawai, audio, video tape atau komputer (Wijaya \& Ramalis, 2012). E-Learning merupakan pembelajaran melalui media elektronik terutama internet (Septian, Ramadhanty, Darhim, \& Prabawanto, 2021; Suryawan \& Permana, 2020; Zain, Ahmad, \& Kalijaga, 2015). Berdasarkan beberapa pengertian tersebut, dapat dikatakan bahwa e-learning adalah pembelajaran yang memanfaatkan teknologi jaringan informasi dan komunikasi seperti aplikasi, internet, dan elektronik/perangkat multimedia.

Karakteristik e-Learning meliputi: (1) memanfaatkan jasa teknologi elektronik; di mana guru dan siswa, siswa dan sesama siswa atau guru dan sesama guru dapat berkomunikasi dengan relatif mudah tanpa dibatasi oleh jarak dan waktu; (2) memanfaatkan keunggulan komputer; (3) menggunakan bahan ajar bersifat mandiri disimpan di komputer sehingga dapat diakses oleh guru dan siswa kapan saja dan dimana saja bila yang bersangkutan memerlukannya (Yazdi, 2012). Kelebihan yang ditawarkan $e$ Learning yaitu: (1) lebih mudah untuk diserap, artinya ialah menggunakan fasilitas 
multimedia yang berupa suatu gambar, teks, animasi, suara dan juga video; (2) jauh lebih efektif di dalam biaya, artinya ialah tidak perlu instruktur, tidak perlu juga minimum audiensi dapat dimana saja dan lain sebagainya; (3) jauh lebih ringkas, artinya ialah tidak banyak mengandung formalitas kelas, langsung kedalam suatu pokok bahasan, mata pelajaran yang sesuai dengan kebutuhan; (4) tersedia dalam 24 jam perhari, artinya ialah penguasaan dalam materi tergantung pada semangat dan daya serap siswa; (5) memanfaatkan jadwal pembelajaran, kurikulum, hasil kemajuan belajar dan hal-hal yang berkaitan dengan administrasi pendidikan dapat dilihat setiap saat dikomputer (Hasbi \& Syarif, 2017). Pada akhirnya, semua bentuk e-learning, apakah itu dalam bentuk aplikasi, program, objek, situs web, dll, dapat memberikan kesempatan belajar bagi individu (Moore, Dickson-Deane, \& Galyen, 2011b).

Berdasarkan uraian di atas, penelitian ini bertujuan untuk mendeskripsikan perspektif mahasiswa pada aspek pola komunikasi dan interaksi dalam pembelajaran daring/e-learning Statistika Matematika. Hasil dari penelitian ini akan dijadikan dasar dalam penelitian selanjutnya terkait $e$-learning pada mata kuliah Statistika Matematika.

\section{METODE PENELITIAN}

Penelitian ini merupakan penelitian deskriptif kualitatif yang bertujuan untuk mendeskripsikan perspektif mahasiswa pada aspek pola komunikasi dan interaksi dalam pembelajaran daring/e-learning Statistika Matematika. Tahap penelitian kualitatif yaitu: (1) identifikasi masalah; (2) penelusuran kepustakaan; (3) maksud dan tujuan penelitian; (4) pengumpulan data; (5) analisa dan pelaporan data; (6) pelaporan (Creswell, 2017). Subjek penelitian ini merupakan hasil sampling jenuh dan berjumlah 91 yaitu seluruh mahasiwa yang mengambil mata kuliah Statistika Matematika di Prodi Pendidikan Matematika Universitas Sarjanawiyata Tamansiswa pada tahun ajaran 2019/2020. Teknik pengumpulan data yang digunakan adalah angket Skala Likert yang terdiri dari pernyataan positif dan negatif. Data yang dihasilkan dalam penelitian ini dianalisis secara statistik deskriptif. Statistik deskriptif adalah statistik yang digunakan untuk menganalisis data dengan cara mendeskripsikan atau menggambarkan data yang telah terkumpul sebagaimana adanya tanpa bermaksud membuat kesimpulan yang berlaku umum atau generalisasi (Sholikhah, 2016). Baik atau tidaknya hasil analisis dipengaruhi oleh keahlian, insight, training dan kemampuan peneliti, peneliti dengan pengalaman dan pengetahuan luas akan menghasilkan analisis data yang lebih baik daripada peneliti dengan pengetahuan dan pengalaman yang sangat kurang dan dangkal (Raco, n.d.). Oleh karena itu, instrumen 
utama dalam penelitian ini adalah peneliti itu sendiri, sedangkan angket Skala Likert merupakan instrumen pendukung.

\section{HASIL DAN PEMBAHASAN}

Data dalam penelitian ini merupakan data angket perspektif mahasiswa pada aspek pola komunikasi dan interaksi dalam pembelajaran daring/e-learning Statistika Matematika. Ringkasan hasil pengisian angket dapat dilihat pada Tabel 1.

Tabel 1. Persentase Prespektif Mahasiswa pada Aspek Pola Komunikasi dan Interaksi

\begin{tabular}{ll}
\hline Indikator & Persentase \\
\hline Kemudahan berinteraksi & $50,00 \%$ \\
Kemudahan menjalin keakraban & $47,02 \%$ \\
Kesalahan komunikasi & $61,94 \%$ \\
Kemudahan mengutarakan pendapat & $50,75 \%$ \\
\hline
\end{tabular}

Tabel 1 menggambarkan bahwa: (1) 50\% mahasiswa menganggap e-learning Statistika Matematika memberikan kemudahan dalam berinteraksi; (2) 47,02\% mahasiswa menganggap e-learning Statistika Matematika memberikan kemudahan dalam menjalin keakraban; (3) 61,94\% mahasiswa mengalami kesalahan komunikasi dalam e-learning Statistika Matematika; (4) 50,75\% mahasiswa menganggap e-learning Statistika Matematika memberikan kemudahan dalam mengutarakan pendapat.

Selain hasil pada Tabel 1, mahasiswa diberikan kesempatan untuk menyampaikan kelebihan, kekurangan, dan saran terhadap e-learning Statistika Matematika yang telah dilaksanakan. Perspektif mahasiswa terkait kelebihan, kekurangan, dan saran terhadap $e$ learning Statistika Matematika dapat dilihat pada Tabel 2.

Tabel 2. Rangkuman Kelebihan, Kekurangan, dan Saran Mahasiswa

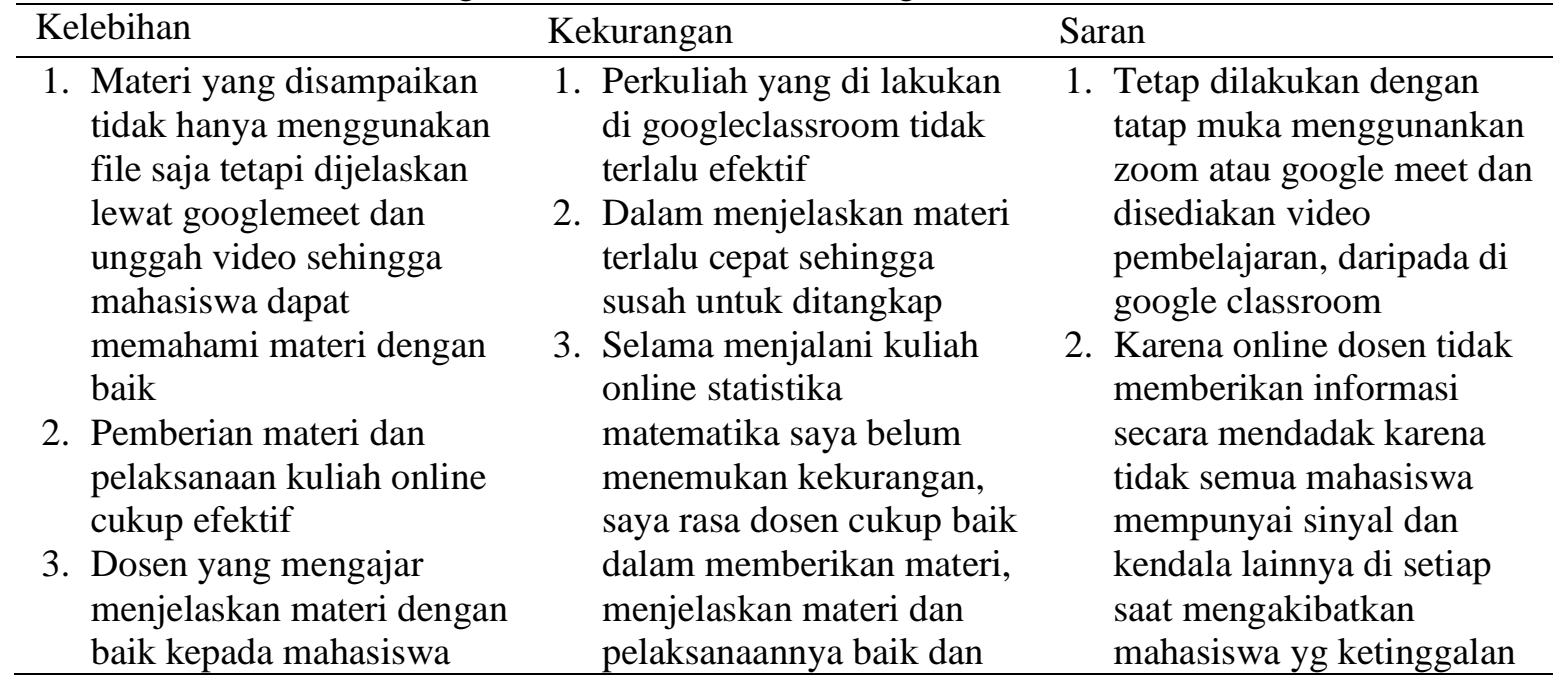




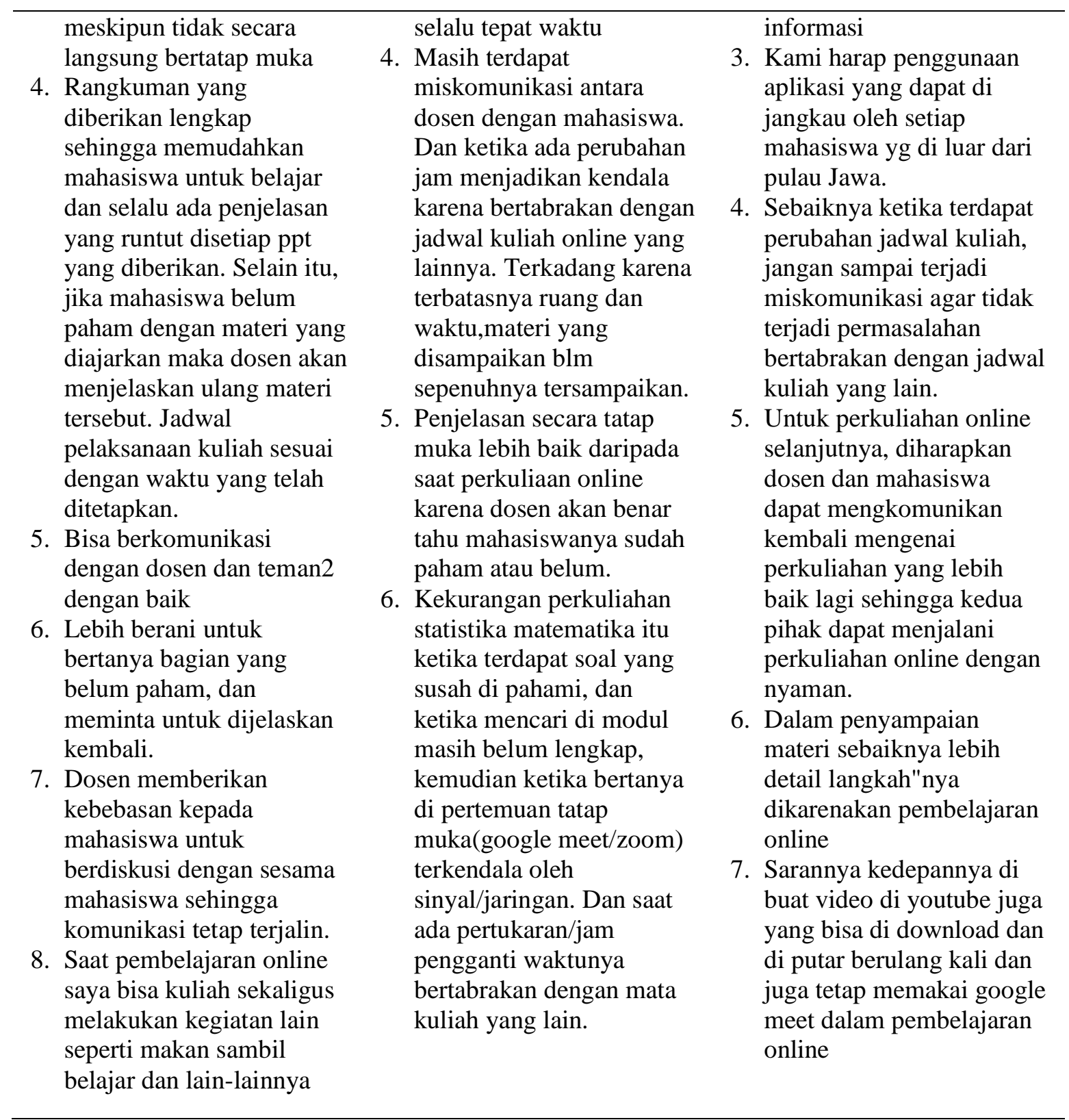

Tabel 2 menunjukkan perspektif mahasiswa terkait kelebihan dan kekurangan $e$ learning Statistika Matematika, sekaligus saran untuk e-learning selanjutnya. Berdasarkan Tabel 2, dapat dipahami bahwa menurut mahasiswa, kelebihan e-learning Statistika Matematika terletak pada keberagaman penggunaan aplikasi, materi kuliah yang lengkap serta suasana pembelajaran yang dirancang oleh pengajar. Di sisi lain, diperoleh beberapa temuan yaitu: (1) terdapat mahasiswa yang berpendapat e-learning Statistika Matematika tidak memiliki kelebihan, aplikasi yang digunakan kurang efektif, e-learning tidak lebih baik daripada tatap muka, dan sering terjadi miskomunikasi antara mahasiswa dengan dosen; (2) dibutuhkan video pembelajaran sebagai pendukung e-learning Statistika 
Matematika. Hasil pada Tabel 2 ini selanjutnya akan digunakan sebagai pendukung data pada Tabel 1.

\section{Keakraban Hubungan}

Berdasarkan uraian sebelumnya, diperoleh bahwa 47,02\% mahasiswa setuju $e$ learning Statistika Matematika yang dilaksanakan memberikan kemudahan dalam menjalin keakraban antara dosen dengan mahasiswa maupun antar mahasiswa. Artinya, 52,98\% mahasiswa mengalami kesulitan untuk menjalin keakraban antara dosen dengan mahasiswa maupun antar mahasiswa dalam e-learning Statistika Matematika. Persentase tersebut menunjukkan bahwa adanya permasalahan dalam e-learning Statistika Matematika hingga mengakibatkan sebagian besar mahasiswa mengalami kesulitan dalam menjalin keakraban.

Keakraban adalah ikatan emosional positif seseorang dengan orang lain karena tingginya frekuensi bertemu sehingga memunculkan sikap pengertian dan dukungan satu sama lain (Smith, 1996; Wahyudi, 2019). Berdasarkan definisi tersebut, dapat dipahami bahwa akrab atau tidaknya seseorang dengan orang lain dipengaruhi frekuensi pertemuan dan sikap yang dimunculkan setelah pertemuan tersebut.

Di masa pandemi Covid-19 ini, tentunya bentuk pertemuan dalam pembelajaran lebih banyak dilakukan secara virtual daripada tatap muka langsung atau bisa dikatakan full virtual. Di sisi lain, frekuensi pertemuan face to face menjadi salah satu indikator utama tingkat keakraban hubungan antar individu maupun kelompok (Wahyudi, 2019). Oleh karena itu, keakraban hubungan sulit terjadi dalam pembelajaran full virtual.

Dalam e-learning Statistika Matematika, pembelajaran dirancang menggunakan aplikasi zoom maupun googlemeet agar terasa seperti tatap muka. Namun, dapat dilihat pada Tabel 2 beberapa mahasiswa masih menggangap bahwa penjelasan secara tatap muka lebih baik daripada virtual sehingga ketika e-learning Statistika Matematika berlangsung mahasiswa tidak memiliki ketertarikan dan keinginan untuk mengikuti perkuliahan. Tidak ada ketertarikan dan keinginan untuk mengikuti perkuliahan ini menunjukkan rendahnya minat belajar mahasiswa dalam e-learning Statistika Matematika (Simbolon, 2014). Di sisi lain, sebanyak 47,02\% mahasiswa dapat dikatakan mempunyai ketertarikan dan keinginan untuk mengikuti perkuliahan, dengan kata lain 47,02\% mahasiswa tersebut mempunyai minat belajar dalam e-learning Statistika Matematika. 


\section{Interaksi dan Kesalahan Komunikasi}

Dua indikator ini dibahas bersamaan karena saling mempengaruhi satu sama lain, artinya keberhasilan interaksi dipengaruhi oleh berhasil atau tidaknya komunikasi antar individu maupun kelompok (Inah, 2015). Di sisi lain, komunikasi akan berhasil dengan baik jika komunikator, pesan yang disampaikan, komunikan, konteks, dan sistem penyampaian juga baik (Lanani, 2013). Dalam e-learning Statistika Matematika, mahasiswa berperan sebagai komunikan yaitu penerima pesan komunikasi.

Tabel 1 menunjukkan bahwa 50\% mahasiswa menganggap e-learning Statistika Matematika memberikan kemudahan dalam berinteraksi dan 61,94\% mahasiswa mengalami kesalahan komunikasi dalam e-learning Statistika Matematika. Kesimpulan yang dapat diambil dari hasil tersebut adalah banyaknya mahasiswa yang mengalami kesalahan komunikasi tidak menjadi tolak ukur kemudahan mahasiswa dalam berinteraksi. Hasil ini memberikan gambaran terdapat beberapa mahasiswa yang mengalami kesalahan dalam berkomunikasi namun masih mampu berinteraksi dengan baik saat e-learning Statistika Matematika. Salah satu unsur yang mampu menjelaskan kondisi tersebut adalah tingginya kemandirian belajar mahasiswa yang mengalami kesalahan komunikasi memilik hubungan signifikan dengan interaksi (Arum, 2015).

Kemandirian belajar atau dikenal dengan self regulated learning (SRL) merupakan kesadaran individu tentang apa yang dipelajari dan bagaimana belajar terhadap proses kognitif dan afektif dalam menyelesaikan suatu tugas akademik tanpa terus menerus menggantungkan diri dari bantuan, pengawasan, dan arahan dari orang lain (Hendriana \& Soemarmo, 2017; Mulyana \& Sumarmo, 2015; Rusman, 2012). Mahasiswa dengan kemandirian belajar tinggi memiliki kemampuan yang tinggi dalam memantau perilaku sendiri melalui tiga langkah yaitu: (1) mengamati dan mengawasi diri sendiri; (2) membandingkan posisi diri dengan standar tertentu; (3) memberikan respon sendiri (Al Aslamiyah, Setyosari, \& Praherdhiono, 2019; Bandura, 2010; Bungsu, Vilardi, Akbar, \& Bernard, 2019). Berdasarkan beberapa teori tersebut, dapat dikatakan bahwa mahasiswa dengan kemandirian belajar tinggi memiliki kemampuan yang tinggi dalam mengontrol perilaku sendiri untuk belajar proses kognitif dan afektif dalam menyelesaikan suatu tugas akademik tanpa terus menerus menggantungkan diri dari bantuan, pengawasan, dan arahan dari orang lain. Hal inilah yang membuat mahasiswa dengan kemandirian belajar tinggi mampu berinteraksi dengan baik meskipun mengalami kesalahan komunikasi. Namun, hanya terdapat $11,94 \%$ mahasiswa yang mampu berinteraksi dengan baik meskipun mengalami kesalahan komunikasi. 


\section{Kemudahan Mengutarakan Pendapat}

Pada Tabel 1, diperoleh hasil bahwa 50,75\% mahasiswa menganggap e-learning Statistika Matematika memberikan kemudahan dalam mengutarakan pendapat, sedangkan sisanya sebesar 49,25\% mahasiswa tidak demikian. Hal ini menunjukkan sebanyak 50,75\% mahasiswa memiliki keberanian mengutarakan pendapat dalam e-learning Statistika Matematika. Keberanian tersebut merupakan indikator seseorang memiliki kepercayaan diri yang tinggi (Marjanti, 2015; Triningtyas, 2016).

Percaya diri adalah sikap positif yang dimiliki individu untuk mengembangkan penilaian positif baik terhadap diri sendiri maupun terhadap lingkungan atau situasi yang dihadapinya sehingga bisa menyelesaikan masalahnya karena tahu apa yang dibutuhkan dalam hidupnya (Nuryanti, Saepudin, Hutajulu, \& Herdiana, 2019; Ratnawati, 2012). Karakteristik seseorang memiliki kepercayaan diri diantaranya: (1) percaya pada kemampuan diri sendiri; (2) bertindak mandiri dalam mengambil keputusan; (3) memiliki konsep diri yang positif; (4) berani mengungkapkan pendapat (Lauster, 2012). Berdasarkan teori tersebut, dapat dipahami bahwa keberanian dalam mengungkapkan pendapat merupakan salah satu karakteristik seseorang memiliki kepercayaan diri. Keberanian mengutarakan pendapat juga merupakan salah satu sikap positif yang dimiliki oleh mahasiswa dalam pembelajaran, sehingga dapat berdampak positif terhadap keberhasilan pembelajaran yang dilaksanakan.

Dalam e-learning Statistika Matematika yang telah dilaksanakan, terdapat 50,75\% mahasiswa yang memiliki keberanian mengutarakan pendapat, dengan kata lain sebanyak 50,75\% mahasiswa memiliki kepercayaan diri dalam pembelajaran. Namun, masih terdapat 49,25\% mahasiswa yang kesulitan dalam mengutarakan pendapat, hal ini berarti bahwa mahasiswa tersebut belum memiliki kepercayaan diri yang baik.

Berdasarkan pembahasan yang telah diuraikan sebelumnya, dapat dipahami bahwa setiap indikator pada aspek pola komunikasi dan interaksi berdampak positif terhadap beberapa aspek lain yaitu minat belajar, kemandirian belajar dan kepercayaan diri. Di sisi lain, minat belajar, kemandirian belajar dan kepercayaan diri berpengaruh positif terhadap hasil belajar matematika secara siginifikan (Amri, 2018; Bungsu et al., 2019; Fajriyah, Nugraha, Akbar, \& Bernard, 2019; Indriawati, 2018; Nurhasanah \& Sobandi, 2016; Ramlah, Firmansyah, \& Zubair, 2015; Setyowati \& Widana, 2016; Sirait, 2016; Sulistyowati, Budiyono, \& Slamet, 2017). Alur keterkaitan beberapa aspek tersebut dapat dilihat pada Gambar 1. 


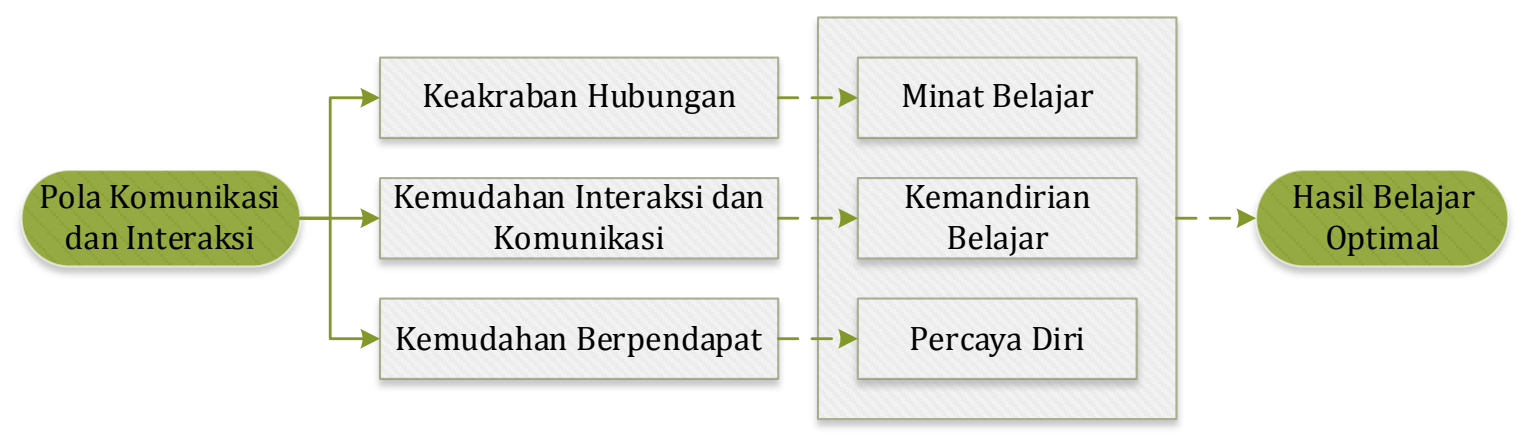

Gambar 1. Alur Pengaruh Pola Komunikasi dan Interaksi terhadap Hasil Belajar

Alur tersebut menggambarkan bahwa, indikator pola komunikasi dan interaksi meliputi keakraban hubungan, kemudahan interaksi dan komunikasi serta kemudahan berpendapat akan memberikan pengaruh positif terhadap minat belajar, kemandirian belajar dan percaya diri yang ketiganya mampu mengoptimalkan hasil belajar. Artinya, secara tidak langsung pola komunikasi dan interaksi mahasiswa mampu mengoptimalkan hasil belajar Statistika Matematika.

\section{KESIMPULAN}

Hasil dari penelitian adalah (1) 50\% mahasiswa menganggap e-learning Statistika Matematika memberikan kemudahan dalam berinteraksi; (2) $47,02 \%$ mahasiswa menganggap e-learning Statistika Matematika memberikan kemudahan dalam menjalin keakraban; (3) 61,94\% mahasiswa mengalami kesalahan komunikasi dalam e-learning Statistika Matematika; (4) 50,75\% mahasiswa menganggap e-learning Statistika Matematika memberikan kemudahan dalam mengutarakan pendapat. Hasil tersebut menunjukkan bahwa tidak seluruh mahasiswa mampu melalukan pola komunikasi dan interaksi dalam e-learning Statistika Matematika dengan baik sesuai indikator yang diberikan. Temuan tersebut merupakan suatu permasalahan dalam e-learning Statistika Matematika yang secara tidak langsung berpengaruh terhadap hasil belajar mahasiswa.

\section{REFERENSI}

Adijaya, N. (2018). Persepsi mahasiswa terhadap materi ajar pada pembelajaran online" yang telah dipublikasi di Jurnal Eduscience Vol. 3/1. Wanastra: Jurnal Bahasa Dan Sastra, 10(2), 105-110.

Adnan, M. (2020). Online learning amid the COVID-19 pandemic: Students perspectives. Journal of Pedagogical Research, 1(2), 45-51. https://doi.org/10.33902/jpsp.2020261309

Al Aslamiyah, T., Setyosari, P., \& Praherdhiono, H. (2019). Blended learning dan kemandirian belajar mahasiswa teknologi pendidikan. Jurnal Kajian Teknologi Pendidikan, 2(2), 109-114. 
Amri, S. (2018). Pengaruh kepercayaan diri (self confidence) berbasis ekstrakurikuler pramuka terhadap prestasi belajar matematika siswa SMA Negeri 6 Kota Bengkulu. Jurnal Pendidikan Matematika Raflesia, 3(2), 156-170.

Annas, A. (2017). Interaksi pengambilan keputusan dan evaluasi kebijakan (Vol. 1). Celebes Media Perkasa.

Arifin, A. (2006). Ilmu komunikasi: sebuah pengantar. Jakarta: Raja Grafindo Persada.

Arum, A. R. (2015). Hubungan antara konsep diri dan interaksi sosial teman sebaya dengan kemandirian belajar pada siswa kelas X SMA Negeri 12 Surabaya. Character: Jurnal Penelitian Psikologi., 3(3).

Bandura, A. (2010). Self-efficacy. The Corsini Encyclopedia of Psychology, 1-3.

Bungsu, T. K., Vilardi, M., Akbar, P., \& Bernard, M. (2019). Pengaruh kemandirian belajar terhadap hasil belajar matematika di SMKN 1 Cihampelas. Journal on Education, 1(2), 382-389.

Chen, E., Kaczmarek, K., \& Ohyama, H. (2020). Student perceptions of distance learning strategies during COVID-19. Journal of Dental Education, (July), 1-2. https://doi.org/10.1002/jdd.12339

Churiyah, M., Sholikhan, S., Filianti, F., \& Sakdiyyah, D. A. (2020). Indonesia education readiness conducting distance learning in covid-19 pandemic situation. International Journal of Multicultural and Multireligious Understanding, 7(6), 491. https://doi.org/10.18415/ijmmu.v7i6.1833

Creswell, J. W. (2017). Research design: pendekatan metode kualitatif, kuantitatif, dan campuran, edisi empat. Yogyakarta: Pustaka Pelajar.

Cucinotta, D., \& Vanelli, M. (2020). WHO declares COVID-19 a pandemic. Acta Bio Medica: Atenei Parmensis, 91(1), 157.

Effendy, O. U. (1990). Ilmu komunikasi teori dan praktek. Remaja Rosdakarya.

Fajriyah, L., Nugraha, Y., Akbar, P., \& Bernard, M. (2019). Pengaruh kemandirian belajar siswa smp terhadap kemampuan penalaran matematis. Journal on Education, 1(2), 288-296.

Hasbi, M., \& Syarif, M. (2017). Penerapan Metode Bayesian Network dalam Aplikasi ELearning Berbasis Web. JUST IT: Jurnal Sistem Informasi, Teknologi Informasi Dan Komputer, 7(2), 36-44.

Hendriana, H., \& Soemarmo, U. (2017). Penilaian pembelajaran matematika edisi revisi. Bandung: PT Refika Aditama.

Inah, E. N. (2015). Peran komunikasi dalam interaksi guru dan siswa. Al-TA'DIB: Jurnal Kajian Ilmu Kependidikan, 8(2), 150-167.

Indriawati, P. (2018). Pengaruh kepercayaan diri dan kecerdasan emosional terhadap hasil belajar mahasiswa Universitas Balikpapan. Jurnal Pendidikan Edutama, 5(2), 1-10.

Lanani, K. (2013). Belajar berkomunikasi dan komunikasi untuk belajar dalam pembelajaran matematika. Infinity Journal, 2(1), 13-25.

Lauster, P. (2012). Tes Kepribadian, Terj. DH Gulo. Jakarta: Bumi Aksara.

Marinoni, G., Van't Land, H., \& Jensen, T. (2020). The impact of Covid-19 on higher education around the world. IAU Global Survey Report.

Marjanti, S. (2015). Upaya meningkatkan rasa percaya diri melalui konseling kelompok bagi siswa x ips 6 sma 2 bae kudus tahun pelajaran 2014/2015. Jurnal Konseling GUSJIGANG, 1(2), 60-68.

Moore, J. L., Dickson-Deane, C., \& Galyen, K. (2011a). e-Learning, online learning, and distance learning environments: Are they the same? The Internet and Higher Education, 14(2), 129-135.

Moore, J. L., Dickson-Deane, C., \& Galyen, K. (2011b). E-Learning, online learning, and distance learning environments: Are they the same? Internet and Higher Education, 
14(2), 129-135. https://doi.org/10.1016/j.iheduc.2010.10.001

Mulyana, A., \& Sumarmo, U. (2015). Meningkatkan kemampuan penalaran matematik dan kemandirian belajar siswa SMP melalui pembelajaran berbasis masalah. Didaktik, 9(1), 40-51.

Nurhasanah, S., \& Sobandi, A. (2016). Minat belajar sebagai determinan hasil belajar siswa. Jurnal Pendidikan Manajemen Perkantoran (JPManper), 1(1), 128-135.

Nuryanti, S., Saepudin, E., Hutajulu, M., \& Herdiana, H. (2019). Meningkatkan kemampuan komunikasi matematis dan kepercayaan diri siswa smp dengan menggunakan pendekatan contextual teaching and learning. Prisma, 8(1), 36. https://doi.org/10.35194/jp.v8i1.381

Quible, Z. K., Johnson, M. H., \& Mott, D. L. (1996). Business communication: principles and applications. Prentice Hall.

Raco, J. (n.d.). Metode penelitian kualitatif: jenis, karakteristik dan keunggulannya.

Ramlah, R., Firmansyah, D., \& Zubair, H. (2015). Pengaruh gaya belajar dan keaktifan siswa terhadap prestasi belajar matematika (survey pada SMP Negeri di Kecamatan Klari Kabupaten Karawang). Majalah Ilmiah SOLUSI, 1(03).

Ratnawati, V. (2012). Percaya diri, body image dan kecenderungan anorexia nervosa pada remaja putri. Persona: Jurnal Psikologi Indonesia, 1(2).

Rizkiani, A., \& Septian, A. (2019). Kemampuan metakognitif siswa SMP dalam pembelajaran matematika dengan menggunakan pendekatan realistic mathematics education ( RME ). UNION: Jurnal Pendidikan Matematika, 7(2), 275-284.

Roestiyah, N. K. (1994). Masalah pengajaran sebagai suatu sistem. Rineka Cipta.

Rusman, M. P. (2012). Model-model pembelajaran mengembangkan profesionalisme guru (edisi kedua). Jakarta: PT Raja Grafindo Persada.

Sardiman, A. M. (2000). Interaksi \& motivasi belajar mengajar. PT Raja Grafindo Persada.

Schneider, S. L., \& Council, M. L. (2020). Distance learning in the era of COVID-19. Archives of Dermatological Research, (0123456789), 3-4. https://doi.org/10.1007/s00403-020-02088-9

Septian, A., Ramadhanty, C. L., Darhim, D., \& Prabawanto, S. (2021). Mathematical problem solving ability and student interest in learning using google classroom. Prosiding International Conference on Education of Suryakancana, 1(1), 155-161.

Septian, A., Sugiarni, R., \& Monariska, E. (2020). The application of android-based geogebra on quadratic equations material toward mathematical creative thinking ability. Al-Jabar: Jurnal Pendidikan Matematika. https://doi.org/10.24042/ajpm.v11i2.6686

Setyowati, D., \& Widana, I. W. (2016). Pengaruh minat, kepercayaan diri, dan kreativitas belajar terhadap hasil belajar matematika. Emasains, 5(1), 66-72.

Sholikhah, A. (2016). Statistik Deskriptif Dalam Penelitian Kualitatif. KOMUNIKA: Jurnal Dakwah Dan Komunikasi, 10(2), 342-362.

Simbolon, N. (2014). Faktor-faktor yang mempengaruhi minat belajar peserta didik. Elementary School Journal Pgsd Fip Unimed, 1(2).

Sirait, E. D. (2016). Pengaruh minat belajar terhadap prestasi Belajar Matematika. Formatif: Jurnal Ilmiah Pendidikan MIPA, 6(1).

Smith, E. R. (1996). What do connectionism and social psychology offer each other? Journal of Personality and Social Psychology, 70(5), 893.

Sofiana, N. (2015). Implementasi blended learning pada mata kuliah extensive listening. Tarbawi: Jurnal Pendidikan Islam, 12(1).

Sulistyowati, F., Budiyono, B., \& Slamet, I. (2017). Problem solving reasoning and problem based instruction in geometry learning. Journal of Physics: Conference 
Series, 895(1). https://doi.org/10.1088/1742-6596/895/1/012045

Suryawan, I. P. P., \& Permana, D. (2020). Media pembelajaran online berbasis geogebra sebagai upaya meningkatkan pemahaman konsep matematika. Prisma, 9(1), 108. https://doi.org/10.35194/jp.v9i1.929

Triningtyas, D. A. (2016). Studi kasus tentang rasa percaya diri, faktor penyebabnya dan upaya memperbaiki dengan menggunakan konseling individual. Counsellia: Jurnal Bimbingan Dan Konseling, 3(1).

Wahyudi, I. (2019). Hubungan antara toleransi sosial, keakraban dengan sumpek pada penghuni pemukiman padat di Kota Surakarta. Jurnal Psikologi, 14(1), 42-53.

Wijaya, A. F. C., \& Ramalis, T. R. (2012). Collaborative Ranking Tasks (CRT) berbantuan E-learning untuk meningkatan keterampilan Generik sains mahasiswa calon guru Fisika. Jurnal Pendidikan Fisika Indonesia, 8(2).

Yazdi, M. (2012). E-learning sebagai media pembelajaran interaktif berbasis teknologi informasi. FORISTEK: Forum Teknik Elektro Dan Teknologi Informasi, 2(1).

Zain, R., Ahmad, Z. A., \& Kalijaga, F. U. I. N. S. (2015). Manajemen perkuliahan berbasis e-learning di perguruan tinggi. Yogyakarta: NCIE CDIE \& Kurnia Kalam Semesta.

Zyainuri, Z., \& Marpanaji, E. (2012). Penerapan e-learning moodle untuk pembelajran siswa yang melaksanakan prakerin. Jurnal Pendidikan Vokasi, 2(3). 